\title{
Erythrobacter longus gen. nov., sp. nov., an Aerobic Bacterium Which Contains Bacteriochlorophyll $a$
}

\author{
TSUNEO SHIBA ${ }^{1}$ AND USIO SIMIDU ${ }^{2}$ \\ Otsuchi Marine Research Center, Ocean Research Institute, University of Tokyo, Akahama, Otsuchi, Iwate, \\ 028-11, ${ }^{1}$ and Ocean Research Institute. University of Tokyo, Nakano, Tokyo, 164, ${ }^{2}$ Japan
}

Four orange-pigmented and seven pink-pigmented strains of bacteria which contained bacteriochlorophyll $a$ were isolated from high-tidal seaweeds, such as Enteromorpha linza (L.) J. Ag. and Porphyra sp. All of the isolates were gram negative. The orange-pigmented bacteria were rods with parallel sides and rounded ends, and the pink-pigmented bacteria were ovoids and short rods. All were motile by means of subpolar flagella. None of the strains produced growth anaerobically in the light. No growth occurred with an atmosphere containing $\mathrm{H}_{2}$ and $\mathrm{CO}_{2}$. All of these bacteria grew aerobically and utilized glucose, pyruvate, acetate, butyrate, and glutamate as sole organic carbon sources. The best growth occurred on complex media formulated for heterotrophic marine bacteria. Biotin was required. Oxidase and catalase were present. Small amounts of acid were produced from a wide range of carbohydrates under microaerobic conditions. Gelatin was hydrolyzed. The strains which we investigated fell into the following three clusters: cluster A, all of the orange strains; cluster B, three pink strains; and cluster $C$, four pink strains. The strains of clusters $B$ and $C$ required thiamine and nicotinic acid and were susceptible to streptomycin. Tween 80 was hydrolyzed and phosphatase activity was produced by the strains of clusters A and B. Pantothenate was required only by the strains of cluster $C$. The guanine-pluscytosine contents of the deoxyribonucleic acids of these organisms ranged from 60 to $64 \mathrm{~mol} \%$. These organisms are recognized here as members of a new genus, Erythrobacter. Although these organisms did not grow phototrophically, the presence of bacteriochlorophyll $a$ indicated that they are most closely related to the Rhodospirillaceae. The type species is Erythrobacter longus, the type strain of which is an orange strain, OCh101 (= IFO 14126).

Bacteriochlorophyll $a$ is a photopigment which until recently had been found only in bacteria that produce growth anaerobically in the light (17). Recently, however, Sato (21) reported the presence of minute amounts of this pigment in the aerobic, methanol-utilizing bacteria Protaminobacter ruber and Pseudomonas sp. strain AM-1. Also, we have frequently isolated orange-and pink-pigmented bacteria which contain bacteriochlorophyll $a$ but which do not grow anaerobically or utilize methanol $(6,24)$. In contrast to the known facultatively anaerobic phototrophic bacteria, such as Thiocapsa roseopersicina, Chloroflexus aurantiacus, and the purple nonsulfur bacteria, the production of bacteriochlorophyll $a$ by these pigmented bacteria is not repressed by aeration $(5,10,18,19)$. Thus, the aerobic orange- and pink-pigmented bacteria are not members of any of the known phototrophic species of bacteria, and they are here recognized as members of new genus. The characteristics of these organisms are presented below.

\section{MATERIALS AND METHODS}

Bacterial strains. Two strains of orange-pigmented bacteria, OCh101 and OCh102, were isolated from the high-tidal seaweed Enteromorpha linza (L.) J. Ag. collected in April 1975. Two other orange organisms, strains OCh103 and OCh104, were isolated from Porphyra sp. collected in February 1978. The pink-pigmented strains OCh110, OCh113, OCh114, OCh115, OCh118, OCh119, and OCh120 were isolated from $E$. linza in February 1978. All of the seaweeds were collected at Aburatsubo Inlet, Kanagawa, Japan. The bacterial isolates were maintained on PPES-II medium (27). All test media were incubated at $20^{\circ} \mathrm{C}$ in the dark unless otherwise stated.

General methods. We Gram stained 24-h-old PPESII slant cultures by using the Hucker modification (26). Motility was examined by the hanging drop method. The sizes and shapes of the cells from agar slant and broth cultures were examined by phase-contrast microscopy. The flagellum stain procedure used was a modification of the Bailey method (26). Spreading growth on agar plates was examined by the methods of Anacker and Ordal (1) and Hendrie et al. (7). Observations were made for up to 3 weeks. The ability of each strain to grow under various physical and chemical 
conditions was investigated by using an agar streaking method in which PPES-II plates were used. The abilities of the strains to grow at $\mathrm{pH} 5.0,6.0,7.0,7.5$, 8.0 , and 9.0 and at $2,10,20,30$, and $37^{\circ} \mathrm{C}$ were determined. Salinity tolerance was also examined. The requirements for $\mathrm{Na}^{+}, \mathrm{K}^{+}, \mathrm{Ca}^{2+}$, and $\mathrm{Mg}^{2+}$ were determined by the method of Colwell and Wiebe (2). The requirements for the following vitamins were tested in four combinations, each lacking one of the four vitamins: biotin $(10 \mu \mathrm{g})$, nicotinic acid $(1 \mathrm{mg})$, thiamine hydrochloride ( $1 \mathrm{mg}$ ), and sodium-pantothenate $(1 \mathrm{mg})$. The vitamins were added to 1 liter of amino acid mixture. The vitamins were added to a mixture of amino acids (13) in artificial seawater (12). One control containing none of the vitamins and the another containing all of them were also used. Results were recorded after three serial transfers in test media. Aerobic utilization and anaerobic utilization of simple organic substrates were tested by using a basal medium which contained (per liter of aged seawater diluted with distilled water to $70 \%$ ) $0.02 \mathrm{~g}$ of yeast extract (Difco Laboratories), $0.001 \mathrm{~g}$ of ferric citrate, $0.05 \mathrm{~g}$ of $\mathrm{NaH}_{2} \mathrm{PO}_{4}, 0.50 \mathrm{~g}$ of $\mathrm{KNO}_{3}, 0.12 \mathrm{~g}$ of tris(hydroxymethyl)aminomethane, $1 \mathrm{mg}$ of thiamine hydrochloride, $1 \mathrm{mg}$ of nicotinic acid, $1 \mathrm{mg}$ of sodium pantothenate, $10 \mu \mathrm{g}$ of biotin, and $1 \mathrm{ml}$ of a trace element solution (16). Organic substrates were added to final concentrations of $0.1 \%$ ( $\mathrm{wt} / \mathrm{vol}$ ), and the $\mathrm{pH}$ was adjusted to 7.5. Anaerobic utilization tests were performed by using a GasPak anaerobic system (BBL Microbiology Systems) with and without illumination. The light intensity was $2,000 \mathrm{~lx}$. The results were recorded after 1 week. Susceptibilities to antibiotics were determined with Showa disks (Showa Co., Tokyo, Japan). The results were recorded after $48 \mathrm{~h}$ of incubation. Acid production from carbohydrates was tested with MOF medium (11). Oxidase activity was determined by the method of Kovács (9); catalase production was detected with $3 \% \mathrm{H}_{2} \mathrm{O}_{2}$. Reduction of nitrate to nitrite was tested after 7 days of incubation in PPES-II broth containing $0.2 \% \mathrm{KNO}_{3}$. The medium used to test for photoautotrophic growth and chemoautotrophic growth with $\mathrm{H}_{2}$ contained (per liter of aged seawater diluted with distilled water to $70 \%$ ) $0.5 \mathrm{~g}$ of $\mathrm{KNO}_{3}, 0.05 \mathrm{~g}$ of $\mathrm{NaH}_{2} \mathrm{PO}_{4}, 0.001 \mathrm{~g}$ of $\mathrm{FeCl}_{3}, 0.12 \mathrm{~g}$ of tris(hydroxymethyl)aminomethane, $1.0 \mathrm{mg}$ of thiamine hydrochloride, $1.0 \mathrm{mg}$ of nicotinic acid, $1.0 \mathrm{mg}$ of sodium pantothenate, $10 \mu \mathrm{g}$ of biotin, and $1.0 \mathrm{ml}$ of a trace element solution (16). The $\mathrm{pH}$ was adjusted to 7.5. Then $20-\mathrm{ml}$ portions of the medium were dispensed into $100-\mathrm{ml}$ test tubes sealed with rubber stoppers fitted with gas-sparging needles and gas exit needles. For photoautotrophic growth tests, cultures were bubbled with filter-sterilized $80 \% \mathrm{H}_{2}-20 \% \mathrm{CO}_{2}$ for $20 \mathrm{~min}$ and were illuminated at a light intensity of 4,000 to $5,000 \mathrm{~lx}$. For chemoautotrophic growth tests, cultures were bubbled with filter-sterilized $70 \% \mathrm{H}_{2}-$ $18 \% \mathrm{CO}_{2}-12 \% \mathrm{O}_{2}$ and were incubated in the dark. The results were recorded after 1 week. Growth in the above-mentioned medium containing $20 \mathrm{mg}$ of yeast extract (Difco) per liter was also determined. The methyl red and Voges-Proskauer tests were performed in a seawater medium which contained $0.5 \%(\mathrm{wt} / \mathrm{vol})$ glucose and $0.5 \%(\mathrm{wt} / \mathrm{vol})$ proteose peptone no. 3 (Difco). The $\mathrm{pH}$ was adjusted to $7.0 . \mathrm{H}_{2} \mathrm{~S}$ production and indole production were tested by using sulfide indole motility medium (Eiken Co., Tokyo, Japan) prepared with aged seawater. To detect the production of slight amounts of indole, $1 \mathrm{ml}$ of chloroform was placed on top of the medium. Indole was detected with $1 \mathrm{ml}$ of Kovács reagent (8). After 4 days of incubation, the test for phosphatase activity was carried out on a PPES-II agar plate containing $0.01 \%$ phenolphthalein diphosphate. Degradation of the following substrates was tested with PPES-II medium as the basal medium: $0.5 \%$ starch; $0.75 \%$ gelatin; $1.0 \%$ chitin; $1.0 \%$ cellulose; and $0.75 \%$ alginate. The hydrolysis of Tween 80 was determined by the method of Colwell and Wiebe (2).

Determination of DNA base composition. Deoxyribonucleic acids (DNAs) were extracted and purified by the method of Marmur (14). The guanine-plus-cytosine $(\mathrm{G}+\mathrm{C})$ contents of the DNAs were calculated from thermal melting point data (15). Flavobacterium $\mathrm{sp}$. strain NCMB 259 DNA $(63.7 \mathrm{~mol} \% \mathrm{G}+\mathrm{C})(3)$ was used as a standard.

Bacterial pigments. The bacterial strains were grown in PPES-II liquid medium through which filter-sterilized air was bubbled. The cells were harvested by centrifugation at $10,000 \mathrm{rpm}$ for $10 \mathrm{~min}$ and were washed with artificial seawater (12). Approximately $0.1 \mathrm{~g}$ of packed cells was suspended in $3 \mathrm{ml}$ of $3 \% \mathrm{NaCl}$ to which $1.6 \mathrm{~g}$ of sucrose was added. Absorption spectra were recorded with a Hitachi model $124 \mathrm{spec}-$ trophotometer equipped with a model 0049 integrating sphere.

Bacteriochlorophyll $a$ was identified by thin-layer chromatography $(4,5,23)$. The pigment was prepared by the method of Sato and Murata (23). Samples of reference bacteriochlorophyll $a_{\mathrm{p}}$ and bacteriochlorophyll $a_{\mathrm{Gg}}$ were prepared from Rhodopseudomonas capsulata NCIB 8254 and Rhodospirillum rubrum NCIB 8255 , respectively.

Electron microscopy. Cultures grown for 1 to 10 days at $20^{\circ} \mathrm{C}$ in PPES-II broth were stained with $1 \%$ phosphotungstic acid ( $\mathrm{pH} 7.0$ ). The samples were examined with a JEOL JEOX-100 CX electron microscope (Nihon Densi Co., Tokyo, Japan).

\section{RESULTS}

The strains which we investigated were divided into the following three clusters: cluster A included the orange-pigmented bacteria OCh101, OCh102, OCh103, and OCh104; cluster B included the pink-pigmented bacteria OCh113, OCh114, and OCh118; and cluster C included the pink-pigmented bacteria OCh110, OCh115, OCh119, and OCh120. All of these strains were gram negative and multiplied by binary fission. The cells of the orange-pigmented bacteria (cluster A) were rods which measured 0.5 to 0.7 by 0.7 to $5.0 \mu \mathrm{m}$ and had parallel sides and rounded ends; they occurred singly and in chains of two to four cells. The cells in old cultures were actively motile by means of one to three subpolar flagella (Fig. 1). Because very few cells were motile in young cultures, we previously (5) had not detected motility in strain OCh101. The cells of the pink-pigmented bacteria (i.e. clusters B and $\mathrm{C}$ ) were ovoids and short rods which measured 0.6 to 1.0 by 0.7 to $2.0 \mu \mathrm{m}$. These cells 


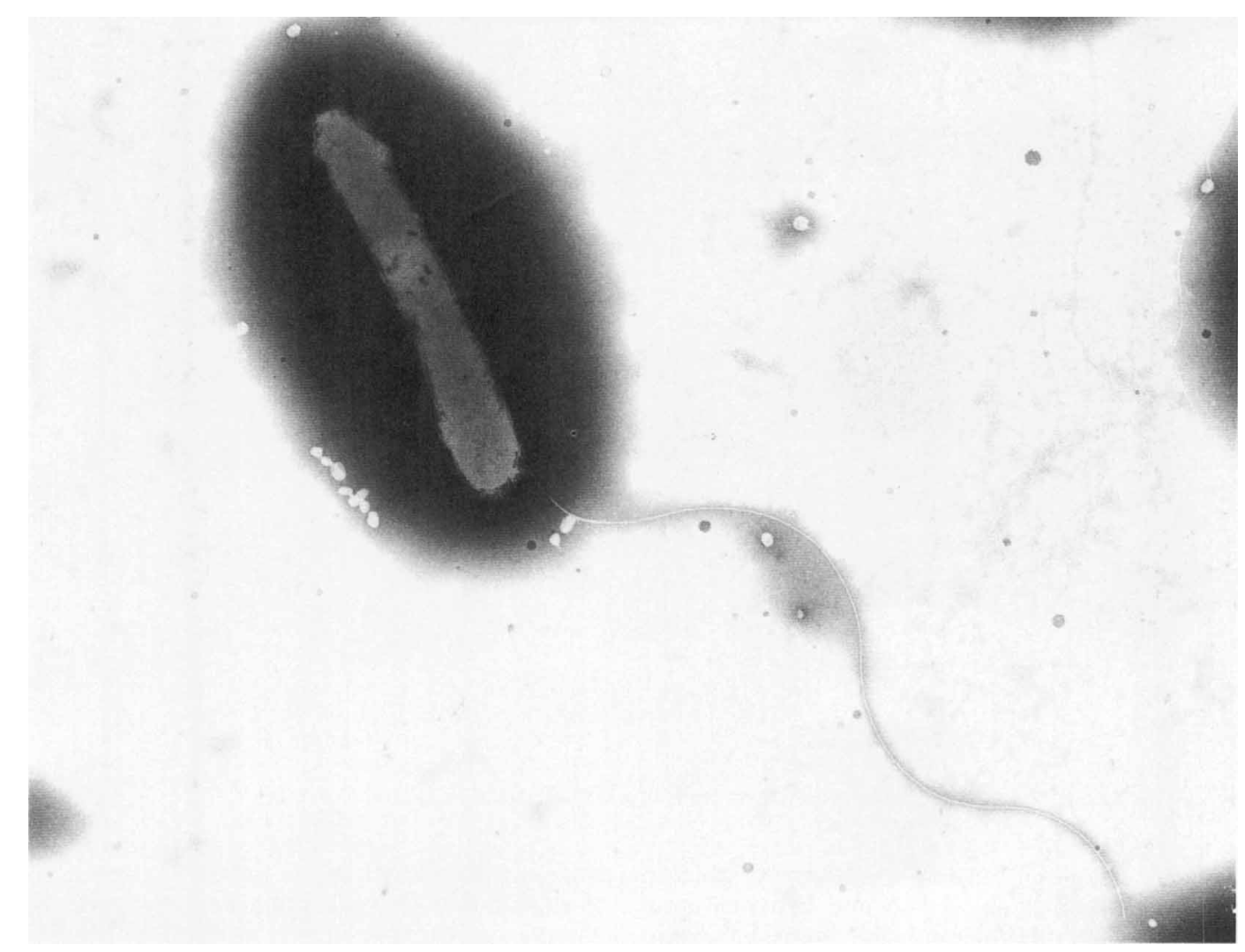

FIG. 1. Electron micrograph of a cell of strain OCh101. $\times 21,323$.

aggregated in young cultures and occurred singly in old cultures. The cells in old cultures were actively motile by means of subpolar flagella (Fig. 2). The number of flagella per cell was one to five (mostly two to three). The absorption spectra of cell suspensions of the orange-pigmented bacteria had a small peak in the $802-$ to 804-nm region and a large peak in the 863- to 867-nm region (Fig. 3). The absorption spectra of the cluster B strains had two large peaks ( 805 to $807 \mathrm{~nm}$ and 868 to $873 \mathrm{~nm}$ ) (Fig. 3). In the infrared region, the spectra of cluster $C$ strains were similar to the spectra of the orange-pigmented bacteria, but the spectra in the 450 - to $550-\mathrm{nm}$ region, which is the carotenoid region, were similar to the spectra of the cluster B strains. The photopigments in all of the strains were identified as bacteriochlorophyll $a$, and the photopigments in strains OCh101 and OCh114 were identified as bacteriochlorophyll $a_{\mathrm{p}}$.

None of the strains was able to grow anaerobically in the light. In addition, no growth occurred with an atmosphere containing $\mathrm{H}_{2}$ plus $\mathrm{CO}_{2}$ or with an atmosphere containing $\mathrm{H}_{2}, \mathrm{CO}_{2}$, and $\mathrm{O}_{2}$. All of the strains were heterotrophic under aerobic conditions. The temperature for maximum growth was between 25 and $30^{\circ} \mathrm{C}$, and the salinity for maximum growth was between 17.5 and $35^{\circ} \%$. The optimum pH was 7.0 to 8.0. The sodium salt ion was required by all of the strains except OCh101. Growth was better with nitrate than with ammonium salt. All of the strains produced a small amount of acid from glucose, fructose, xylose, arabinose, maltose, sucrose, cellobiose, ribose, sorbitol, and mannitol in the upper region of MOF medium covered with sterilized liquid paraffin. Spreading growth was not observed for any of the strains.

Other characteristics are summarized in Table 1. Although all of the strains utilized acetate, pyruvate, butyrate, glucose, and glutamate, growth of the strains of cluster A was generally feeble. With strains of cluster A, only growth with butyrate was better than that of strains of clusters B and C. Glycolate, malate, succinate, citrate, and lactate were also utilized by the strains of clusters B and C. Methanol was not utilized by any of the strains. OCh113 and OCh119 showed feeble growth with formic acid. Biotin was required by all of the strains. Thiamine and nicotinic acid were required by the strains of clusters B and C, whereas pantothe- 


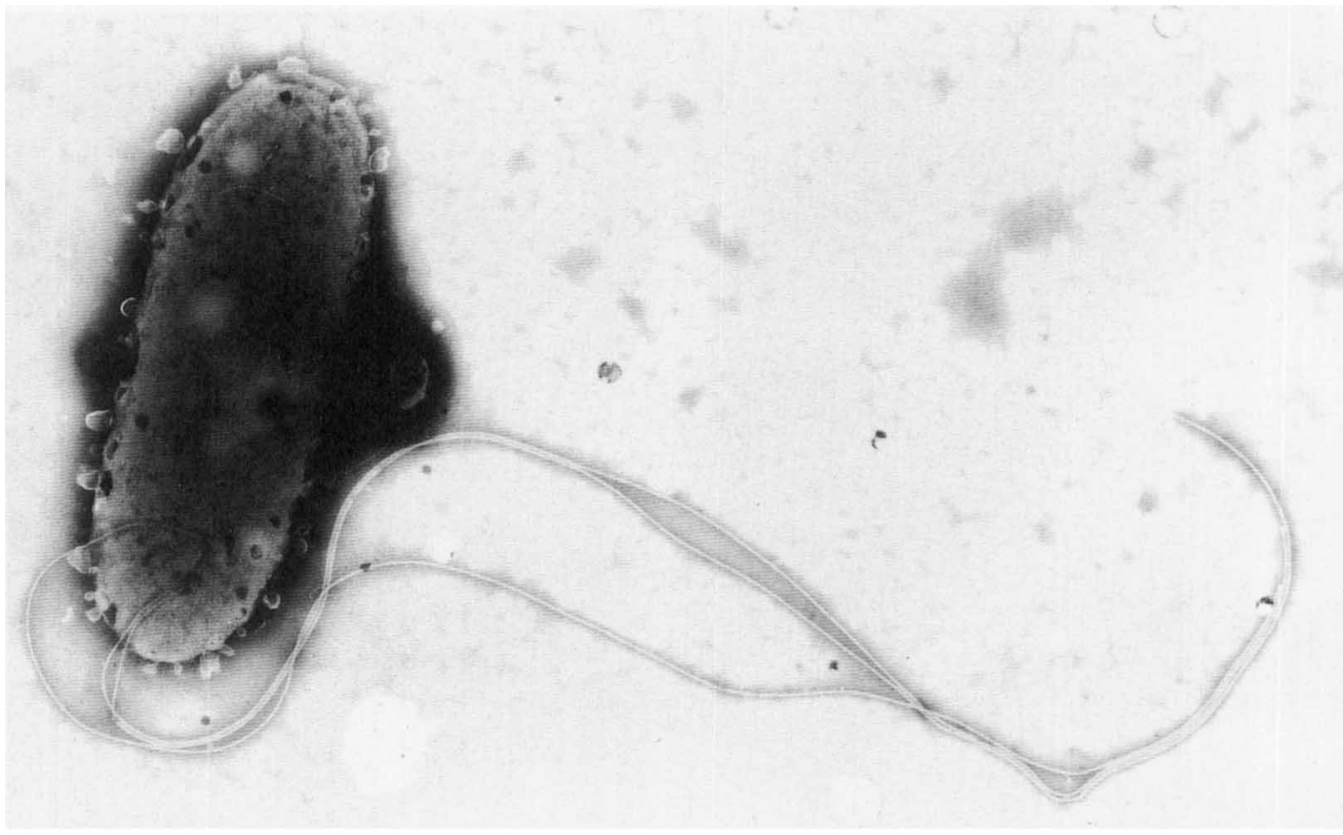

FIG. 2. Electron micrograph of a cell of strain OCh114. $\times 27,746$.

nate was required only by the strains of cluster C. The strains of clusters A and B hydrolyzed Tween 80 and produced phosphatase. Susceptibility to streptomycin was observed in the strains $\hat{c} \hat{i}$ clusters $B$ and $C$, whereas the strains of cluster B were susceptible to polymyxin B. Nitrate was reduced to nitrite by strains OCh101, OCh114, and OCh118. Strains OCh101

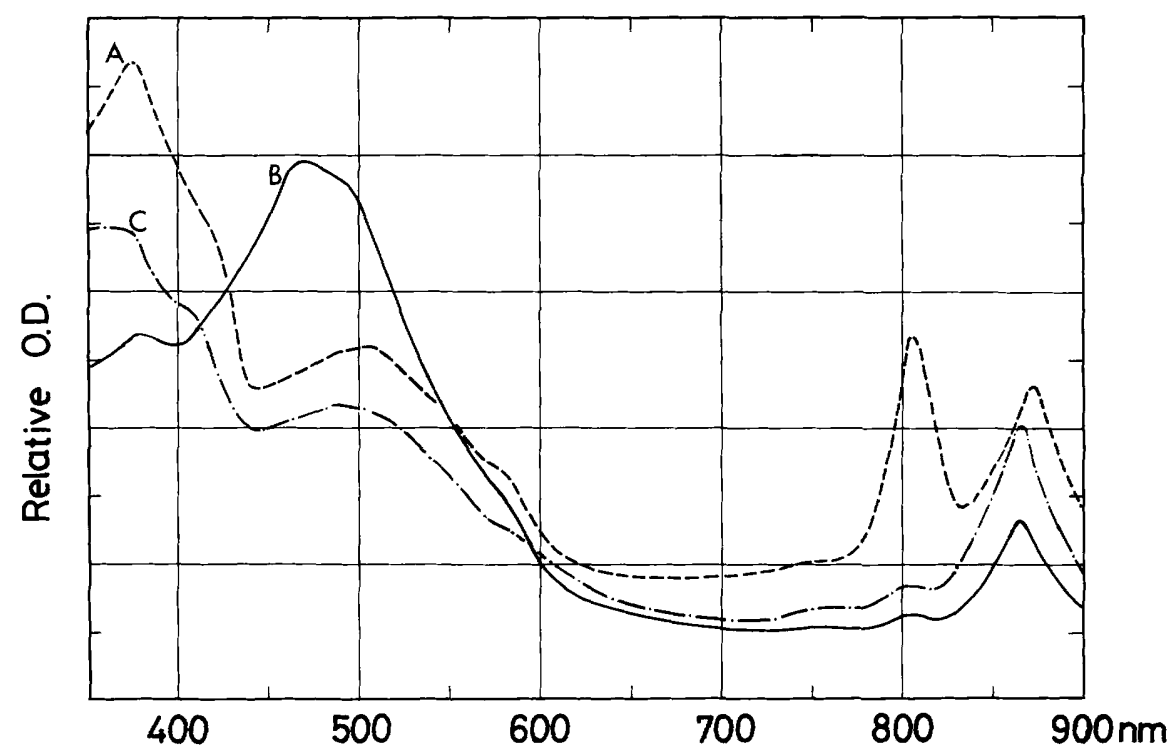

FIG. 3. Absorption spectra of cell suspensions. Line A, Strain OCh113; line B, strain OCh102; line C, strain OCh110. The optical densities (O.D.) of the peaks for strain OCh102 $(0.13 \mathrm{~g}$ [wet weight] per $3 \mathrm{ml})$ were as follows: $866 \mathrm{~nm}, 0.615 ; 806 \mathrm{~nm}, 0.275 ; 470 \mathrm{~nm}, 1.790 ;$ and $377 \mathrm{~nm}, 1.200$. For strain OCh110 $(0.11 \mathrm{~g} / 3 \mathrm{ml})$ the optical densities of the peaks were: $864 \mathrm{~nm}, 0.570 ; 803 \mathrm{~nm}, 0.273 ; 480 \mathrm{~nm}, 0.568$; and $373 \mathrm{~nm}, 0.775$. And for strain OCh113 $(0.08 \mathrm{~g} / 3 \mathrm{ml})$, the optical densities of the peaks were: $869 \mathrm{~nm}, 0.690 ; 807 \mathrm{~nm}, 0.793 ; 510 \mathrm{~nm}, 0.772$; and $378 \mathrm{~nm}, 1.412$. 
TABLE 1. Characteristics of the strains studied

\begin{tabular}{|c|c|c|c|}
\hline \multirow{2}{*}{ Character } & \multicolumn{3}{|c|}{$\begin{array}{l}\text { No. of positive strains in } \\
\text { cluster: }\end{array}$} \\
\hline & $\begin{array}{c}\mathrm{A} \\
(n=4)\end{array}$ & $\begin{array}{c}\mathrm{B} \\
(n=3)\end{array}$ & $\begin{array}{c}\mathrm{C} \\
(n=4)\end{array}$ \\
\hline \multicolumn{4}{|l|}{ Utilization of: } \\
\hline Glucose & 4 & 3 & 4 \\
\hline Acetate & 4 & 3 & 4 \\
\hline Pyruvate & 4 & 3 & 4 \\
\hline Glutamate & 4 & 3 & 4 \\
\hline Butyrate & 4 & 3 & 4 \\
\hline Citrate & 0 & 3 & 4 \\
\hline Malate & 0 & 3 & 4 \\
\hline Succinate & 0 & 3 & 4 \\
\hline Glycolate & 0 & 3 & 4 \\
\hline Lactate & 0 & 3 & 4 \\
\hline Formic acid & 0 & 1 & 1 \\
\hline Methanol & 0 & 0 & 0 \\
\hline \multicolumn{4}{|l|}{ Requirement for: } \\
\hline Biotin & 4 & 3 & 4 \\
\hline Thiamine & 0 & 3 & 4 \\
\hline Pantothenate & 0 & 0 & 4 \\
\hline Nicotinic acid & 0 & 3 & 4 \\
\hline \multicolumn{4}{|l|}{ Susceptibility to: } \\
\hline Chloramphenicol $(100 \mu g)$ & 4 & 3 & 4 \\
\hline Penicillin $(20 \mathrm{U})$ & 4 & 3 & 4 \\
\hline Streptomycin $(50 \mu \mathrm{g})$ & 0 & 3 & 4 \\
\hline Tetracycline $(50 \mu \mathrm{g})$ & 0 & 0 & 0 \\
\hline Fusidic acid $(0.5 \mu \mathrm{g})$ & 4 & 3 & 4 \\
\hline Polymyxin B (100 U) & 0 & 3 & 0 \\
\hline \multicolumn{4}{|l|}{ Hydrolysis of: } \\
\hline Tween 80 & 4 & 3 & 0 \\
\hline Alginate & 2 & 0 & 0 \\
\hline Gelatin & 4 & 3 & 4 \\
\hline Starch & 0 & 0 & 0 \\
\hline Chitin & 0 & 0 & 0 \\
\hline Cellulose & 0 & 0 & 0 \\
\hline Phosphatase production & 4 & 3 & 0 \\
\hline $\mathrm{NO}_{3}$ reduction to $\mathrm{NO}_{2}$ & 1 & 2 & 0 \\
\hline Voges-Proskauer reaction & 0 & 0 & 0 \\
\hline Methyl red test & 0 & 0 & 0 \\
\hline $\mathrm{H}_{2} \mathrm{~S}$ production & 0 & 0 & 0 \\
\hline Indole production & 4 & 3 & 4 \\
\hline
\end{tabular}

and OCh102 hydrolyzed alginate.

The $\mathrm{G}+\mathrm{C}$ contents of the DNAs of the strains ranged from 60 to $64 \mathrm{~mol} \%$.

\section{DISCUSSION}

The presence of bacteriochlorophyll $a$ and the inability to grow under anaerobic conditions were the most striking characteristics of the strains investigated. Although a number of aerobic strains of photopigment-containing bacteria have been reported previously, most of these strains are mutants induced from facultatively anaerobic phototrophic bacteria. Only two strains of $P$. ruber and Pseudomonas sp. strain AM-1 are known to be inhabitants of natural environments, and these strains contain only small amounts of bacteriochlorophyll $a$ (22).

As shown previously (24), orange- and pinkpigmented bacteria which contain bacteriochlorophyll $a$ widely inhabit aerobic marine environments. The population densities reported are $10^{2}$ to $10^{3}$ cells per $\mathrm{cm}^{2}$ of high-tidal seaweeds and $10^{3}$ cells per $\mathrm{ml}$ of surface seawater. It was calculated that there were roughly $10^{3}$ cells per $g$ of beach sand. In contrast to the known phototrophic bacteria, the synthesis of bacteriochlorophyll $a$ by strains OCh101 and OCh114 was not repressed at full atmospheric oxygen tension but rather was repressed by an insufficient supply of oxygen (5). The large population densities in aerobic environments, together with the ability to synthesize pigment aerobically, indicate that the aerobic photopigment-containing bacteria have adapted to aerobic environments.

Although the presence of bacteriochlorophyll $a$ indicates that the strains which we studied are most closely related to the Rhodospirillaceae, the ability to hydrolyze gelatin, Tween 80 , and alginate suggests that these organisms have evolved into chemoorganotrophs. Except for the hydrolysis of gelatin by Rhodopseudomonas gelatinosa, no hydrolyzing activity has been reported for the Rhodospirillaceae (17). Maximal growth in half- to full-strength seawater medium and subpolar flagella are characteristic of the organisms. Subpolar flagellation has been reported only for Rhodopseudomonas palustris (17). The aerobic organisms also differ from $P$. ruber and Pseudomonas sp. strain AM-1 by not utilizing methanol. Other distinguishing characteristics of the methylotrophs are that they do not require any growth factor and they are polary flagellated $(20,25)$. Thus, we place the aerobic, orange- and pink-pigmented bacteria into a new genus, Erythrobacter. This genus is most closely related to the Rhodospirillaceae. However, assignment to this family must be based on a revision of the family because the family is currently limited to bacteria which are anaerobic phototrophs (17).

Erythrobacter gen. nov. (Gr. adj. erythrus red; M. L. masc. n. bacter rod or staff; M. L. mas. $n$. Erythrobacter red rod).

Ovoid to rod-shaped cells. Motile by means of subpolar flagella. Gram negative. Cells are orange or pink, contain bacteriochlorophyll $a$ and carotenoids, and multiply by binary fission.

Aerobic chemoorganotrophs. Cultures do not grow anaerobically in the light. No autotrophic growth occurs with $\mathrm{H}_{2}$. Methanol is not utilized. Halophilic. Biotin is required. Some strains require thiamine, nicotinic acid, and pantothenate. Although small amounts of acid are produced from a wide range of carbohydrates under microaerobic conditions, metabolism is predom. 
inantly respiratory. The Voges-Proskauer and methyl red tests are negative. Gelatin is hydrolyzed. Some strains hydrolyze Tween 80 and alginate. Oxidase and catalase are produced. Susceptible to chloramphenicol, penicillin, and tetracycline; not susceptible to nalidixic acid.

The $\mathrm{G}+\mathrm{C}$ content of the DNA ranges from 60 to $64 \mathrm{~mol} \%$.

The type species is Erythrobacter longus.

Erythrobacter longus sp. nov. (L. adj. longus long).

Gram-negative, orange-pigmented rods, 0.5 by 1.0 to $5.0 \mu \mathrm{m}$. Motile by means of subpolar flagella. Cells contain bacteriochlorophyll $a$ and carotenoids. Aerobic chemoorganotrophs. No autotrophic growth occurs. Methanol is not utilized. Metabolism is predominantly respiratory.

The temperature for maximum growth is 25 to $30^{\circ} \mathrm{C}$, and the salinity for maximum growth is 17 to $35^{\circ \%} \%$. The optimum $\mathrm{pH}$ is 7.0 to 8.0 . Biotin is required for growth. Phosphatase, catalase, and oxidase are produced. Some strains reduce nitrate to nitrite. The Voges-Proskauer and methyl red tests are negative. $\mathrm{H}_{2} \mathrm{~S}$ is not produced. Indole is produced. Tween 80 and gelatin are hydrolyzed. Some strains hydrolyze alginate. Susceptible to chloramphenicol, penicillin, tetracycline, and fusidic acid; not susceptible to streptomycin, polymyxin $\mathrm{B}$, or nalidixic acid.

The $\mathrm{G}+\mathrm{C}$ content of the DNA is 60 to 64 mol\%.

Habitat: Marine environments.

Type strain: OCh101, a culture of which has been deposited in the Institute for Fermentation (IFO), Osaka, Japan, under the number 14126. The description of the type strain is as follows. Gram-negative rods, 0.5 by 1.0 to $5.0 \mu \mathrm{m}$. Motile by means of subpolar flagella. Contains bacteriochlorophyll $a_{\mathrm{p}}$ and carotenoids, giving colonies an orange color. Aerobic and chemoorganotrophic. No autotrophic growth occurs. Metabolism is predominantly respiratory. Growth occurs with butyrate; feeble growth occurs with acetate, pyruvate, glucose, and glutamate. Methanol is not utilized.

The temperature for maximum growth is $30^{\circ} \mathrm{C}$, and the salinity for maximum growth is 17 to $26^{\circ \%}$. The optimum $\mathrm{pH}$ is 7.0.

Biotin is required for growth. Phosphatase, catalase, and oxidase are produced. Nitrate is reduced to nitrite. The Voges-Proskauer and methyl red tests are negative. $\mathrm{H}_{2} \mathrm{~S}$ is not produced. Indole is produced. Tween 80 , gelatin, and alginate are hydrolyzed. Susceptible to chloramphenicol, penicillin, tetracycline, and fucidic acid; not susceptible to streptomycin, polymyxin $\mathrm{B}$, or nalidixic acid.

The $\mathrm{G}+\mathrm{C}$ content of the DNA is $60.7 \mathrm{~mol} \%$.

Although the strains of the genus fall into three clusters, only one species is recognized at present. Any additional proposals of new species must await future investigation of more isolates.

\section{ACKNOWLEDGMENT}

We thank K. Harashima of the University of Tokyo for helpful advice during the course of this investigation.

\section{REPRINT REQUESTS}

Address reprint requests to: Dr. T. Shiba, Otsuchi Marine Research Center, Ocean Research Institute, University of Tokyo, Akahama, Otsuchi, Iwate, 028-11, Japan.

\section{LITERATURE CITED}

1. Anacker, O. D., and E. J. Ordal. 1959. Studies on the myxobacterium Chondrococcus columnaris. I. Serological typing. J. Bacteriol. 78:25-32.

2. Colwell, R. R., and W. J. Wiebe. 1970. "Core" characteristics for use in classifying aerobic, heterotrophic bacteria by numerical taxonomy. Bull. Ga. Acad. Sci. 28:165-185.

3. De Ley, J., and J. Van Muylem. 1963. Some applications of deoxyribonucleic acid base composition in bacterial taxonomy. Antonie van Leeuwenhoek J. Microbiol. Serol. 29:344-358.

4. Egger, K. 1962. Dünnschichtchromatographie der Chloroplastenpigmente. Planta 58:664-667.

5. Harashima, K., J. Hayasaki, T. Ikari, and T. Shiba. 1980. $\mathrm{O}_{2}$-stimulated synthesis of bacteriochlorophyll and carotenoids in marine bacteria. Plant Cell Physiol. 21:12831294.

6. Harashima, K., T. Shiba, T. Totsuka, U. Simidu, and N. Taga. 1978. Occurrence of bacteriochlorophyll $a$ in a strain of an aerobic heterotrophic bacterium. Agric. Biol. Chem. 42:1627-1628.

7. Hendrie, M. S., T. G. Mitchell, and J. M. Shewan. 1968. The identification of yellow-pigmented rods, p. 67-78. In B. M. Gibbs and D. A. Shapton (ed.), Identification methods for microbiologists, Part B. Academic Press, Inc., London.

8. Kovács, N. 1928. Eine vereinfachte Methode zum Nachweis der Indolbildung durch Bakterien. Z. Immunitaetsforsch. Exp. Ther. 55:311-315.

9. Kovács, N. 1956. Identification of Pseudomonas pyocyanea by the oxidase reaction. Nature (London) 178:703.

10. Lascelles, J. 1959. Adaptation to form bacteriochlorophyll in Rhodopseudomonas sphaeroides: changes in activity of enzymes concerned in pyrrole synthesis. Biochem. J. 72:508-518.

11. Leifson, E. 1963 . Determination of carbohydrate metabolism of marine bacteria. J. Bacteriol. 85:1183-1184.

12. Lymann, J., and R. H. Fleming. 1940. Composition of seawater. J. Mar. Res. 3:134-140.

13. MacLeod, R. A. 1968 . On the role of inorganic ions in the physiology of marine bacteria, p. 95-126. In M. R. Droop and E. J. F. Wood (ed.), Advances in microbiology of the sea. Academic Press, Inc., London.

14. Marmur, J. 1961. A procedure for the isolation of deoxyribonucleic acid from micro-organisms. J. Mol. Biol. 3:208-218.

15. Marmur, J., and P. Doty. 1962. Determination of the base composition of deoxyribonucleic acid from its thermal denaturation temperature. J. Mol. Biol. 5:109-118.

16. Pfennig, N., and K. D. Lippert. 1966. Über das Vitamin $\mathrm{B}_{12}$-Bedürfnis phototropher Schwefelbakterien. Arch. Microbiol, 55:245-256.

17. Pfennig, N., and H. G. Trüper. 1974. The phototrophic bacteria, p. 24-75. In R. E. Buchanan and N. E. Gibbons (ed.), Bergey's manual of determinative bacteriology, 8th ed. The Williams \& Wilkins Co., Baltimore.

18. Pierson, B. K., and R. W. Castenholz. 1971. Bacteriochlorophylls in gliding filamentous prokaryotes from hot springs. Nature (London) New Biol. 233:25-27. 
19. Pierson, B. K., and R. W. Castenholz. 1974. A phototrophic gliding filamentous bacterium of hot springs. Chloroflexus aurantiacus, gen. and sp. nov. Arch. Microbiol. 100:5-24

20. Quayle, J. R. 1961. Metabolism of $C_{1}$ compounds in autotrophic and heterotrophic microorganisms. Annu. Rev. Microbiol. 15:119-152.

21. Sato, K. 1978. Bacteriochlorophyll formation by facultative methylotrophs, Protaminobacter ruber and Pseudomonas AM-1. FEBS Lett. 85:207-210.

22. Sato, K., and S. Shimizu. 1979. The conditions for bacteriochlorophyll formation and ultrastructure of a methanolutilizing bacterium, Protaminobacter ruber, classified as non-photosynthetic bacteria. Agric. Biol. Chem. 43:1669_ 1675 .

23. Sato, N., and N. Murata. 1978. Preparation of chlorophyll $a$, chlorophyll $b$ and bacteriochlorophyll $a$ by means of column chromatography with diethylaminoethylcellulose. Biochim. Biophys. Acta 501:103-111.

24. Shiba, T., U. Simidu, and N. Taga. 1979. Distribution of aerobic bacteria which contain bacteriochlorophyll $a$. Appl. Environ. Microbiol. 38:43-45.

25. Shimizu, S., T. Kobayashi, K. Sato, K. Ohmiya, M. Mori, T. Nishimura, and M. Sasaki. 1978. Cultivation of methanol-utilizing bacterium Protaminobacter ruber and its cell composition. Nippon Nogei Kagaku Kaishi 52:477-484.

26. Society of American Bacteriologists. 1957. Manual of microbiological methods. McGraw-Hill Book Co.. New York.

27. Taga, N. 1968. Some ecological aspects of marine bacteria in the Kuroshio current. Bull. Misaki Mar. Biol. Inst. Kyoto Univ. 12:222-226. 